\title{
IN VITRO INOCULATION OF ASPARAGUS OFFICINALIS TISSUE CULTURE SHOOTS WITH FUSARIUM PROLIFERA TUM
}

\author{
A.K.MoHD OMAR', N.A.R. NIK NoRULAiNi², \\ B. SALLEH ${ }^{3}$ and R.A.R. ISKANDAR' \\ ${ }^{1}$ School of Industrial Technology, \\ ${ }^{2}$ School of Distance Education, \\ ${ }^{3}$ School of Biological Sciences, Universiti Sains Malaysia, 11800, Penang, Malaysia
}

\begin{abstract}
Artificially inoculated asparagus tissue culture plantlets with a virulent fungus, Fusarium proliferatum showed signs of infection as early as 4 days after inoculation. Macroscopic observations revealed presence of early symptoms such as necrotic lesions at the affected area and light microscopic examinations clearly revealed the post-penetration events that took place including the destruction of surrounding cells. However, little is known of the hyphal activity or advancement on the host's surface at the initial stage after inoculation. Scanning electron microscopic examination clearly revealed the hyphal advancement on the surface and the mode of entrance into the host tissues beneath. Four days after inoculation, the fungi proceeded to spread out from the inoculation point onto the host surface which eventually developed into a sparse network of both aerial and non-aerial hyphae. Non-aerial hyphae form a network of mycelium that adheres to the surface and it's movement appeared to be oriented towards the stomata. Hyphal penetration occurs more often through the stomata, natural openings or wounds. In some cases, the hyphae crossed over the stomatal opening without entering the host tissues. At places where the cuticle layer is absent or not well developed the hyphae successfully grew in between the epidermal cells into the tissues beneath.
\end{abstract}

Key words: Tissue culture/Asparagus officinalis/shoots/Artificial inoculstion/Fusarium proliferatum.

\section{INTRODUCTION}

In pathogen infected tissues, the pre- and post-penetration as well as results of infection can provide valuable knowledge regarding the virulence and epidemiology of the fungus involved. As a result of infection the physiological changes in diseased plants are usually manifested in visible symptoms which may be mild or severe, depending on the nature and aggressiveness of the pathogen and the susceptibility of the host plant. The physiological changes occurring in the diseased plant can be witnessed in the anatomical and morphological changes ('morbid anatomy') which constitute the visible symptoms. The visible symptoms such as necrosis or rot are in part related to the pathogenicity mechanisms of the pathogen, at least at the early stages of infection.

Histological examination very often can reveal the post-penetration development of the fungus and histological changes of the infected cells (Jewell et al. 1979; Nik Norulaini 1992 a,b). Scanning electron microscopy observations are useful in studying the development of the fungus on the epidermal surface, it's subsequent colonization on the surface and mode of penetration into the tissues beneath (Ab. Rahmane/a/. 1987; Jacobiefa/. 1982). 
Fusarium has been known to infect a wide range of crops in Malaysia (Sabariah 1987). One of the most serious diseases, namely crown rot, was described and the pathogen was identified as F. proliferatum (Salleh 1990). The other casual pathogens include F. solani, F. nygamai and F. oxysporum. In the field, primary infection of F. prolifeatum is through wounding particularly those caused by insects (Salleh et al. 1998). Field symptoms, however, were reproduced by an artificial inoculation of asparagus in the greenhouse. The symptoms-include irregular reddish brown lesions on infected stems followed by stem girdling, crown and root rot and finally the entire plant die (Salleh et al. 1998).

The objective of this paper is to study the pre-penetration development of $F$. proliferatum, the causal agent of crown and root rot, into asparagus tissue culture shoots.

\section{MATERIALS AND METHODS}

Production of tissue culture shoots as hosts

One year-old asparagus (Asparagus officinalis L.) plants cv. Mary Washington 500 (MW 500) raised from seeds in the greenhouse (Salleh et al. 1996) were used as source of explants. Spears about $20 \mathrm{~cm}$ long and $0.25 \mathrm{~cm}$ in diameter were cut into $2.5 \mathrm{~cm}$ in length and surface-sterilized with $10 \%$ bleach $(\mathrm{v} / \mathrm{v})(5.25 \%$ sodium hypochlorite). A few drops of Tween 20 emulsifier was added to enhance spread of the disinfectant. The segments were rinsed three times with sterile distilled water and blotted on sterile filter papers to remove the bleach. The sterilized segments were cut into one node segments of $1 \mathrm{~cm}$ each and cultured on Murashige and Skoog (1962) medium with the following concentrations in $\mathrm{mgl}^{11}$ : NAA 0.3 , kinetin 0.1, thiamine-HCl 1.0, pyridoxine-HCl 5.0, nicotinic acid 5.0, myo-inositol 100.0, adenine sulphate dehydrate 40, sucrose 25000 and supplemented with Difco Bacto malt extract 500, $\mathrm{NaH}_{2} \mathrm{PO}_{4} \cdot \mathrm{H}_{2} \mathrm{O}$ 170. Each culture bottle (500 ml) contained three segments and incubated at $27^{\circ} \mathrm{C}$ with continuous lighting at 1000 lux. Multiple shoots that formed from 1 to 6 weeks were used as hosts.

\section{Preparation of inoculum}

The fungus, F. proliferatum Culture No. 851, was collected from infected asparagus plants cv MW 500 from the field. The fungus was kept in liquid nitrogen $\left(-196^{\circ} \mathrm{C}\right)$ for several months (deposited at the Fusarium Culture Collection Unit, USM, Penang) before culturing on potato dextrose agar (PDA) (Salleh \& Sulaiman 1984). Four-day old cultures on PDA were used as inoculum. 
In vitro Inoculation of Asparagus officinalis Tissue Culture Shoots - A.K.. Mohd. Omar el al.

Inoculation of tissue culture shoots

One to six weeks old shoots produced were used as hosts. Three to four mm of the epidermis were carefully removed from the shoots as inoculation sites. The sites of inoculation were at the middle, basal and apex of the plantlets. Mycelial plugs, about $1 \mathrm{~mm}^{3}$ taken from the periphery of the fungal colony were placed on the inoculation sites. Scanning electron microscopic examination of infected shoot segments showing pathological changes were fixed in 5\% glutaraldehyde for 1 hour, washed with phosphate buffer, fixed in $4 \%$ osmium tetroxide for 3 - 4 hours and then washed in phosphate buffer. The tissues were dehydrated through an alcohol series and critical point-dried using a critical point drier. They were then coated with gold in an EMS-76M gold coater and examined with a JEOL JSM35C scanning electron microscope.

\section{RESULTS AND DISCUSSION}

Twenty four hours after inoculation the hyphae began to spread progressively from the inoculum. Four days later, the hyphae ramified into sparse network of mycelia that grew close to the surface of the tissue (Fig. 1A). Little aerial hyphae were observed. Colonized stems will be overwhelmed by mycelia after six days of inoculation. Removal of the mycelia from infected stems revealed early stages of necrotic lesions even at areas away from the inoculated sites (Fig. IB). Likewise, inoculation with conidia on mature asparagus stems with $F$. proliferatum showed occasional lesions (Tan 1991). These reddish lesions are normally small, about 0.5 $\mathrm{mm}$ in length and can only be detected with a dissecting scope. The emergence of hyphae from beneath the tissues through necrotic spots were also observed, indicating existence of mycelial network within the cells.

Mature asparagus stems have developed a cuticle layer that inhibits the penetration of the fungus. Penetration can, however, take place in cracks and crevices (Nik Norulaini \& Salleh 1990). This was observed in the basal part of the stem where the tissues were well covered with cuticle layer, or waxy deposits. The hyphae were seen entering the tissues via the stomatal opening (Fig. 1C) or the natural cracks (Fig. ID). Movement of hyphae in the groove in between cells was also apparent. No direct penetration in between cells was discovered even after exhaustive examination.

Mature tissues also offer resistance to any mycotoxins that might be released by the fungus. In a study by Tan (1991), an incorporation of culture filtrate that contains toxins into a culture caused lesions on asparagus stems. The toxins were translocated through the base of the stem from the media. Direct inoculation of the culture filtrate on the mature stem failed to induce any lesion.

A significant difference in the cuticle development was observed at the apical areas of the inoculated shoots, where ramification of hyphal networks on the surface show the mycelia moving close to the surface (Fig. IE). The lack of waxy deposits may influence penetration of the fungus as observed, since penetration between 
epidermal cells took place (Fig. IF). Stomatal penetration of a single hypha was observed near the apical region, where the tissues were younger with little mechanical barrier, since there were only scant deposits of wax in the region.
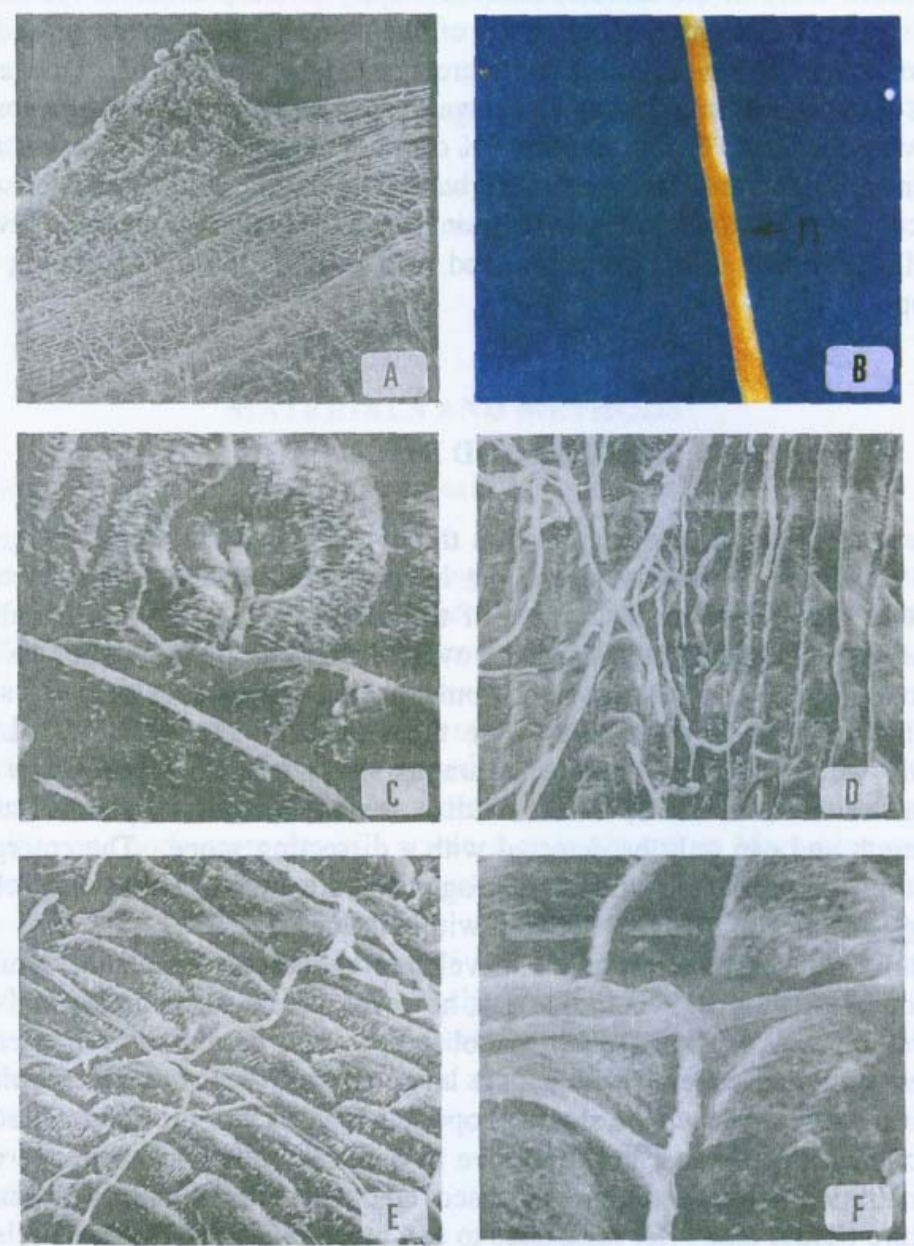

Figure 1: Growth and penetration of $F$. proliferatum on asparagus tissue culture shoots.

A: Ramifications of hypha into sparse network 4 days after inoculation (DAI) B: Necrosis (n) on inoculated stem 8 DAI

$\mathrm{C}$ : A single hypha entering the stomata

D: Hypha entering the tissue via natural cracks

E: Hypha network moving close to the surface

F: Penetration in between epidermal cells 
In vitro Inoculation of Asparagus officinalis Tissue Culture Shoots - A.K. Mohd. Omar et al.

Although field infection is known to be via wounding, the in vitro SEM examinations indicated that penetration can occur quite commonly through stomatal openings in the basal region. In younger tissues penetration can take place both between cells and through the stomata. In more mature parts of the tissue, the cuticle layer forms an effective mechanical barrier to the penetration of the fungus.

\section{CONCLUSION}

Although Fusarium spp. have been associated with - and - caused many plant diseases, little has been studied on the host defence mechanisms or the fungus activities on the host. Extensive review revealed the importance and potential of Fusarium as disease-causing organisms, especially in the tropics (Salleh \& Sulaiman 1984).

With this preliminary finding it is hoped that this will offer a better understanding of the infection mode in nature and the pathogen's infectious capabilities on a large number of plants. Further work is needed to understand the biochemical and physiological aspects of fusarium-related diseases. This approach could also lead to a screen for asparagus varieties resistant to fusarium-related diseases, such as have been used to screen non-fusarium resistant plant varieties (Utkhede 1986), and to study resistance mechanisms (Dolan \& Coffey 1985; Diner et al. 1984), evaluation of susceptibility (Sylvestre-Guinot \& Delatour 1983) and surface interaction (Nik Norulaini \& Salleh 1990). The in vitro approach may offer a simplified and rapid screening method.

\section{REFERENCES}

AB. RAHMAN, N.N., A.M. DINER, SKILLINO, D.D. and D.F. KARNOSKY. 1987. In vitro responses of conifer adventitious shoots and call! inoculated with Gremmemella abietina. Forest Science 33:4: 1041-1053.

DINER, A.M., R.L. MOTT, and H.V. AMERSON. 1984. Cultured cells of white pine show genetic resistance to axenic blister rust hyphae. Science 24:407-408.

DOLAN, T.E., and M.D. COFFEY. 1986. Laboratory screening technique for assessing resistance of four avocade to Phytophtora cinnamoni. Plant Disease. 70: 115-118.

JACOBI, W.R., H.V. AMERSON and R.L. MOTT. 1982. Microscopy of cultured loblolly pine seedlings and callus inoculated with Cronartiumfusiforme. Phytopathology 71:138-143.

JEWELL, F.F., P.C. JEWELL and C.H. WALKINSHAW. 1979. Histopathology of the initiation of resistance-zones in juvenile slash pine to Cronartium quercuum. f. sp. Jusiforme. Phytopathologisch Meditterranica 19: 8-12.

MURASHIGE, T. and T. SKOOG. 1962. A revised medium for rapid growth and bioassays with tobacco tissue culture. Physiologia Plantarum . 15:473-479.

NIK NORULAINI N.A.R. 1992a. Assessment of in vitro inoculation of asparagus with conidia and culture filtrate of Fusarium proliferation. Proceedings of the 4* JSPS-VCC Seminar on Integrated Engineering, 13th - 14th October 1992, Kyoto, Japan.

NIK NORULAINI N.A.R. 1992b. In vitro Inoculation of asparagus with conidial suspension and culture filtrate of Fusarium oxysporum Schlect. f. asparag. Proceedings of Asia-Pacific Conference on Agricultural Biotechnology, August 20-24 1992, Beijing, China. 
NIK NORULAINI, N.A.R and B. SALLEH. 1990. In vitro inoculations of asparagus tissue culture of plantlets with vegetative hyphaof Fusarium proliferatum. Proceedings of the $3^{1 * *}$ International Conference on Plant Protection in the Tropics. 20-23 March 1990, Genting Highlands, Malaysia.

SABARIAH, H. 1987. Diseases of asparagus. B.Sc. thesis, School of Biological Sciences, Universiti Sains Malaysia, Penang, Malaysia.

SALLEH, B. 1990. Crown rot caused by Fusarium proliferatum (Matsushima) Nirenberg; A new disease of asparagus in Malaysia. Proceedings of The $3^{\text {th }}$ International Conference on Plant Protection in the Topics. Genting Highlands, Malaysia, p. 343 (Abstract).

SALLEH, B. and B. SULAIMAN. 1984. Fusaria associated with naturally diseased plants in Penang. Journal of Plants Protection in the Tropics 1: 47-53.

SALLEH,B., A. SAFINAT,L. JULAa and C.H. TEO. 1996. Brown spot caused by Curvalaria spp., a new disease of asparagus. BIOTROP1A9: 26-37.

SYLVESTER-GUINOT, G. and C. DELATOUR. 1983. Possibility's di'appreciation de la sensibiliti'e du genre Larix au Lachnellula willkommii (hartig) Dennis par inoculations artificielles. Full Annales Scientia Forsswiststand., 40(4) 337-354.

TAN, L.H. 1991. Penginolculatan batang dan pucuk kultur tisu muda asparagus secara in vitro dengan ampaian konidia dan turasan kultur Fusarium proliferatum (Matsushima) Nirenberg. B.Sc. thesis, School of Biological sciences, Universiti Sains Malaysia, Penang, Malaysia.

SALLEH, B., S.M. HAKAM, D. FACHRI, B.A.Y. INSANUL, A. K.ASMAL, L. LAHMUDDIN and S. NURDUATI. 1998. Current status of asparagus diseases in Southeast Asia (SEA). Asean Food Journal (Submitted).

UTKHEDE, R.S. 1986. In vitro screening of the world apple germplasm collection for resistance to Phytophthora cactorum crown rot. Scientia Horticulturae, 29:205-210. 